\title{
AGGRAVATING EFFECT OF ARTERIAL HYPERTENSION ON THE COURSE OF CHRONIC OBSTRUCTIVE PULMONARY DISEASE IN PATIENTS WITH COMORBID PATHOLOGY
}

DOI: $10.36740 /$ WLek202104130

\author{
Viktoriia V. Rodionova, Olha O. Boiko \\ STATE INSTITUTION «DNIPROPETROVSK MEDICAL ACADEMY OF THE MINISTRY OF HEALTH OF UKRAINE», DNIPRO, UKRAINE
}

\begin{abstract}
The aim: To study the effect of arterial hypertension on the course of chronic obstructive pulmonary disease in patients with comorbid pathology.

Materials and methods: The prospective study included 61 patients with COPD: 32 stable male patients with COPD with comorbid arterial hypertension of stage II 1-3 degrees and 29 stable outpatients of men with COPD of clinical groups A-D with impaired respiratory function II-IV according to GOLD. All patients, in accordance with the goals and objectives of the study, were divided into 2 groups: group I consisted of men with isolated COPD, middle age - 56.0 (8.5) years, average duration of the disease - 16.2 (1.3) years, Group II consisted of male patients with COPD and arterial hypertension (AH), middle age - 59.5 (7.5). The patients underwent a general clinical examination, which included an assessment of complaints, anamnestic data, and a physical examination. The severity of COPD was determined on the basis of the frequency of exacerbations during the year, assessment of dyspnea using the mMRS scale, spirographic data. Statistical materials were processed using the STATISTICA 10.0 program.

Results: In group I, 20 patients (69\%) complained of dyspnea during exercise, in group II - 25 patients $(78 \%)(p=0.4), 28$ patients $(96.5 \%)$ complained of cough with vague sputum. group and 30 patients in group II (93.8\%) $(p=0.09)$. When assessing the number of exacerbations over the past year, it was determined that patients with isolated COPD had an average of $1.0(1.0 ; 2.0)$ exacerbations, and patients with COPD and AH - 2.0 $(1.0 ; 3.0)(p=0.06)$. According to the CAT questionnaire, the following data were obtained: in group I $-9.0(8.0 ; 11.0)$ points, and in group II $-17.5(10.0 ; 20.0)$ points $(p=0.02)$. When conducting spirographic studies, a statistically significant more expressive bronchial obstruction was found in patients with COPD and comorbid hypertension.

Conclusions: The presence of comorbid arterial hypertension leads to the intermittent effect of diseases: according to the results of mMRC and SAT test, ailments for COPD were examined, they have a more severe course of underlying seizure in the presence of concomitant arterial hypertension. Clinical manifestations in patients with COPD and $\mathrm{H}$ are more severe compared to clinical manifestations in patients without aggravated diseases of the cardiovascular system. Concomitant arterial hypertension enhances the manifestations of bronchial obstruction, in the same way as with patients with isolated COPD.
\end{abstract}

KEY WORDS: hypertension, COPD, comorbid pathology

Wiad Lek. 2021;74(4):973-976

\section{INTRODUCTION}

Polymorbidity is one of the features of the modern clinical picture of internal diseases, and arterial hypertension $(\mathrm{AH})$ and chronic obstructive pulmonary diseases remain the most common diseases of the adult population of developed countries [1]. One of the most common nosological forms is chronic obstructive pulmonary disease (COPD) [2,3]. According to WHO experts, by 2030, COPD will become the third leading cause of death worldwide $[2,4]$.

COPD is a chronic disease with a progressive course, which ranks third in the structure of causes of death in the world according to WHO. In 2016, there were 251 million cases of COPD worldwide, and in 2015 - 3,170,000 deaths of patients with COPD, which is $5 \%$ of all deaths in the world. More than $90 \%$ of deaths from COPD occur in low- and middle-income countries [1,2].

The main target organs in COPD are the bronchi and lungs, but at a certain stage in the development of the disease, other organs and systems are affected. The most significant correlation was found between COPD and car- diovascular disease. It has been established that COPD is a precursor to the development of cardiovascular diseases and / or its exacerbation $[2,3,4,5]$. It was found that there is a relationship between an increase in arterial wall stiffness and the severity of bronchial obstruction in patients, and a decrease in FEV1 is associated with a high risk of cardiovascular mortality [2,5]. Over the past 30 years, the spread of cardiovascular diseases in Ukraine has increased 3.5 times, and the mortality rate from them - by $46 \%$. In the structure of morbidity, the first are arterial hypertension (AH) $-41 \%$ and ischemic heart disease $-28 \%[6,7,8]$. The prevalence of arterial hypertension is also significantly higher in patients with COPD [7,2]. The common mechanisms of development of many extrapulmonary manifestations are chronic systemic inflammation, oxidative stress, and endothelial dysfunction [9]. The combination of CVD and COPD increases the pathological changes inherent in each disease separately, significantly changes the clinical picture, course and consequences of each of the associated diseases, leads to a significant complication [10]. 


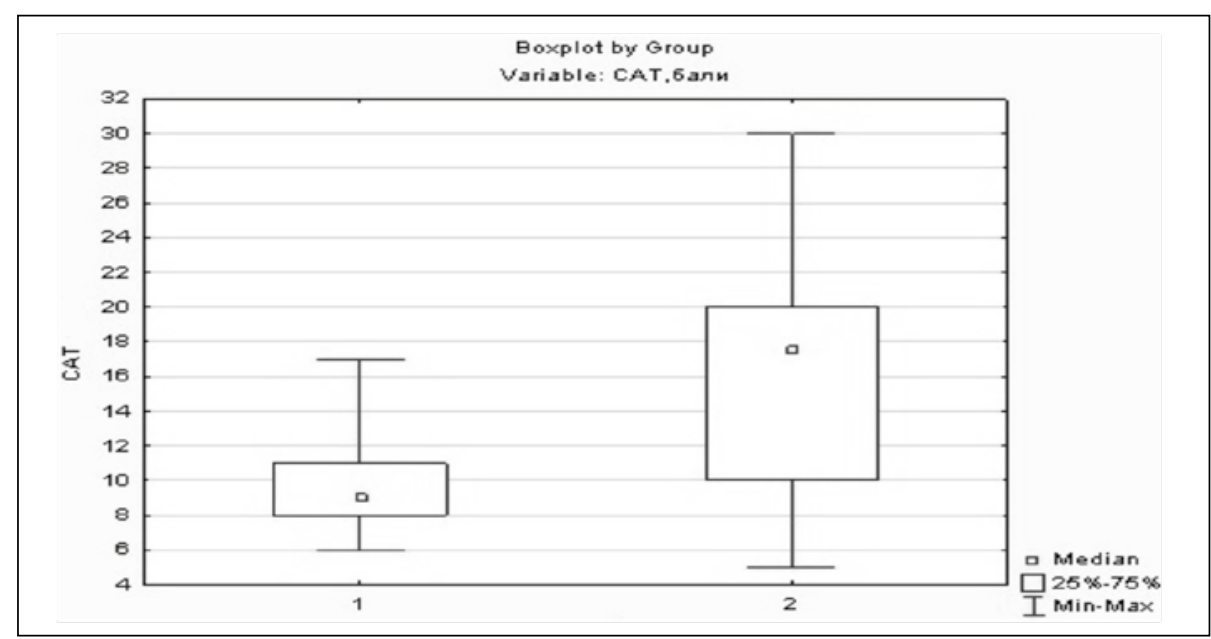

Fig. 1. Results of the CAT questionnairein patients

Table 1. Respiratory function indicators in patients.

\begin{tabular}{cccc}
\hline & Group I & Group II & p \\
\hline FVC, \% Me [25\%-75\%] & $98,0(89,0 ; 115,0)$ & $92,0(59,0 ; 108,0)$ & 0,2 \\
\hline FEV ${ }_{1} \%$ Me $[25 \%-75 \%]$ & $73,0(50,0 ; 91,0)$ & $44,0(32,0 ; 65,0)$ & 0,03 \\
\hline FEV $\%$ Me $[25 \%-75 \%]$ & $66,0(36,0 ; 77,4)$ & $48,0(25,8 ; 75,0)$ & 0,04 \\
\hline MEF 75, \% Me [25\%-75\%] & $78,0(48,0 ; 89,0)$ & $26,0(20,0 ; 67,0)$ & 0,02 \\
\hline MEF 50, \% Me [25\%-75\%] & $73,0(10,0 ; 76,0)$ & $23,0(8,0 ; 60,0)$ & 0,02 \\
\hline MEF 25, \% Me [25\%-75\%] & $22,0(11,0 ; 36,0)$ & $41,0(18,0 ; 62,0)$ & 0,6 \\
\hline PEF, \% Me [25\%-75\%] & $75,0(56,0 ; 89,0)$ & $42,0(22,0 ; 59,0)$ & 0,5 \\
\hline IC_F, \% Me [25\%-75\%] & $43,0(40,0 ; 92,0)$ & $62,0(45,0 ; 87,0)$ & 0,8 \\
\hline
\end{tabular}

\section{THE AIM}

To investigate the effect of arterial hypertension on the course of chronic obstructive pulmonary disease.

\section{MATERIALS AND METHODS}

The prospective study included 61 patients with COPD: 29 stable outpatients of men with COPD of clinical groups A-D with impaired respiratory function II - IV according to GOLD and 32 stable male patients with COPD with comorbid arterial hypertension of II stage 1-3 degrees. The patients were treated at the municipal non-profit institution «City Clinical Hospital No. 4» of the Dnipropetrovsk City Council during 2018-2020. The criteria for the inclusion of patients in the study were: the clinical diagnosis of COPD was verified in accordance with the recommendations of GOLD 2019 [2], the diagnosis of arterial hypertension was verified based on the recommendations for the treatment of arterial hypertension of the European Society of Cardiology and the European Society of Arterial Hypertension, 2018 [8], informed consent of patients for inclusion in research and processing of personal data. The exclusion criteria from the study were: the age of patients over 80 years old, a history of acute cardiovascular events, clinically significant cardiac arrhythmias, previously diagnosed diabetes mellitus, kidney disease, malignant neoplasms, and undergoing surgery over the last year. All patients, in accordance with the goals and objectives of the study, were divided into 2 groups: group I consisted of men with isolated COPD, middle age - 56.0 (8.5) years, average duration of the disease - 16.2 (1.3) years Group II included men with $\mathrm{COPD}$ and arterial hypertension $(\mathrm{AH})$, middle age - 59.5 (7.5), with an average duration of COPD - 15.9 (1.7) years. Both groups were comparable in age and duration of COPD ( $p>0.05)$. In group I, 3 patients belonged to category A COPD, 11 patients to category $B, 13$ patients to category C, and 2 patients to category $D$. In group II, 2 patients had COPD category A, 14 - category B, 14 - category C and 2 patients of category D. Patients underwent a general clinical examination, which included an assessment of complaints, anamnestic data, and a physical examination. The severity of COPD was determined based on the frequency of exacerbations during the year, assessment of dyspnea using the mMRS scale (The modified medical research counsil dyspnea scale) and COPD assessment test, spirographic data (forced expiratory volume in 1 second (FEV1), forced vital lung capacity (FVC), their ratio - FEV1 / FVC). The results of the study were processed using statistical methods. To identify the relationship between the indicators, a correlation analysis of paired measurements was carried out using the method of K. Pearson's coefficient $(\chi 2)$, since the data had a distribution other than normal. Those indicators in which the level of disagreement was $\mathrm{p}<0.05$ were considered significant. The material was calculated using the Microsoft Excel 2000 software package, the statistical processing of the research materials was performed on a personal computer using the STATISTICA 10.0 licensed software (StatSoft Inc., Serial No. AGAR909E415822FA) [11]. 


\section{RESULTS AND DISCUSSION}

In group I, 20 patients (69\%) complained of dyspnea during exercise, in group II - 25 patients $(78 \%)(\mathrm{p}=0.4), 28 \mathrm{pa}-$ tients $(96.5 \%)$ complained of cough with vague sputum. group and 30 patients in group II $(93.8 \%)(\mathrm{p}=0.09)$. When assessing the number of exacerbations over the past year, it was determined that patients with isolated COPD had an average of $1.0(1.0 ; 2.0)$ exacerbations, and patients with COPD and AH - $2.0(1.0 ; 3.0)(\mathrm{p}=0.06)$. Despite the fact that the level of obstruction is not always correlated with the severity of symptoms in patients, the CAT and mMRC questionnaire was used [12].

The severity of dyspnea (mMRC scale) in patients of group I was $1.5(1.0 ; 2.0)$ points, in patients of group II $2.0(1.0 ; 3.0)$ points $(\mathrm{p}=0.07)$. Based on the data of the CAT questionnaire, a more complete scoring of respiratory symptoms and their impact on the life of patients was carried out, so in group I received $9.0(8.0 ; 11.0)$ points, and in group II - $17.5(100 ; 20.0)$ points $(\mathrm{p}=0.02)$ (Fig. 1$)$.

When conducting spirographic studies, a statistically significant more pronounced bronchial obstruction was found in patients with COPD and comorbid hypertension (Table 1).

The results obtained indicate a more severe course of COPD in the presence of comorbid arterial hypertension, which, in turn, has a greater impact on the quality of life of patients. The results obtained are comparable with the data of the ECLIPSE study, according to which the presence of hypertension in patients with COPD was associated with more severe dyspnea [13].The results obtained in our study are confirmed by the data of Caram L. M., Ferrari R., Naves C. R., which indicate that patients with concomitant hypertension have more severe obstruction. Comorbidities are highly prevalent in COPD, regardless of its severity. Certain risk factors for CVD, themselves classified as diseases (including smoking, dyslipidemia, and depression), appear to be more prevalent in patients with mild-to-moderate COPD. $[13,14,15]$. In COPD, comorbid diseases increase the risk of hospitalization and death. Also, comorbidity significantly increases the cost of medical care for such patients. Many of patients with COPD, concomitant pathology worsens the quality of their life and survival, reduces their activity. The presence of concomitant pathology can lead to late diagnosis of COPD [16]. Previous studies have established that COPD is associated with hypertension, kidney diseases and coronary heart diseases (CHD), which this study confirmed. CHD is frequently underdiagnosed in people with COPD; this is important as the coexistence of CHD and COPD results in a worse prognosis than if a patient has one disease or the other. This study demonstrated that individuals with COPD, compared with people without, were more likely to have heart failure, peripheral vascular disease, and cerebrovascular disease consistent with higher rates of hypertension and CHD, with smoking as a common risk factor. Research by Rutten et al identified a prevalence of $20.5 \%$ for heart failure in people with COPD - compared with $6.4 \%$ in this study - when screened for the condition using a number of diagnostic tests including an echocar- diogram. It is therefore likely that the true prevalence of heart failure in COPD is higher than found in this study, because patients with COPD are not routinely screened for heart failure [17]. The early impairment of renal function in patients with COPD and comorbid cardiovascular disease is of interest. Unfortunately, this process is asymptomatic for a long time, but it aggravates the course of pulmonary pathology. This issue is not given due attention, which is reflected in the literature [18].

\section{CONCLUSIONS}

The presence of comorbid arterial hypertension leads to the intermittent effect of diseases: according to the results of mMRC and SAT feeding, ailments for COPD were examined, they have a more severe course of underlying seizure in the presence of concomitant arterial hypertension. Clinical manifestations in patients with COPD and $\mathrm{AH}$ are more severe compared to clinical manifestations in patients without aggravated diseases of the cardiovascular system. Concomitant arterial hypertension enhances the manifestations of bronchial obstruction, in the same way as with patients with isolated COPD.

\section{REFERENCES}

1. Yatsenko 0.V. Porivnyal'na kharakterystyka rivnya pokaznykiv matrychnoyi metalloproteinazy- 9 i vysokochutlyvoho S-reaktyvnoho bilka pry komorbidnosti perebihu arterial'noyi hipertenziyi ta khronichnoyi obstruktyvnoyi khvoroby lehen' [Comparative characterization of the level of indicators of matrix metalloproteinase- 9 and highly sensitive C-reactive protein in the comorbid course of hypertension and chronic obstructive pulmonary disease]. Scientific Journal "Science Rise: Medical Science". 2017;5(13): 32-6 (In Ukrainian).

2. Global Initiative for Chronic Obstructive Lung Diseases (GOLD). Global strategy for diagnosis, management, and prevention of chronic obstructive pulmonary disease. NHLBI. WHO workshop report [Internet]. WHO.-2018.

3. Boiko 0., Rodionova V. The effect of nutritional status on the degree of arterial hypertension.Chest.2020;158(4). doi:https://doi.org/10.1016/j. chest.2020.08.155

4. Cavaillès A., Brinchault Rabin G., Dixmier A. et al. Comorbidities of COPD. European Respiratory Review. 2013; 22:454-475.

5. Ho T., Cusack R.P., Chaudhary N. et al. Under- and over-diagnosis of COPD: a global perspective. Breathe (Sheff). 2019;15(1): 24-35 doi: 10.1183/20734735.0346-2018.

6. Yin H., Yin S., Lin Q. et al. Prevalence of comorbidities in chronic obstructive pulmonary disease patients: A meta-analysis. Medicine (Baltimore). 2017;96 (19):e6836.

7. Raherison C., Ouaalaya E.H., Bernady A. et al. Comorbidities and COPD severity in a clinic-based cohort. BMC Pulm Med. 2018;18(1): 117 doi: 10.1186/s12890-018-0684-7.

8. Williams B., Mancia G., Spiering W. et al. 2018 ESC/ESH Guidelines for the management of arterial hypertension. European Heart Journal. 2018;39(33): 3021-104.

9. Pertseva T.A., Bialik H. KHOZL: sovremennoye sostoyaniye problemy. [COPD: current state of the problem]. Ukrainian pulmonological journal. 2010; 1: 18-19. (In Russian). 
10. Yatsenko 0.V.Porivnyal'na kharakterystyka rivnya pokaznykiv matryksnoy metalloproteinazy-9 i vysokochutlyvoho S-reaktyvnoho bilka pry komorbidnosti perebihu arterial'noyi hipertenziyi ta khronichnoyi obstruktyvnoyi khvoroby lehen' [Comparative characterization of the level of indicators of matrix metalloproteinase- 9 and highly sensitive C-reactive protein in the comorbid course of hypertension and chronic obstructive pulmonary disease]. Scientific Journal "Science Rise: Medical Science". 2017;5(13): 32-6. (In Ukrainian).

11. Lang T.A., Sesik M. Yak opysuvaty statystyku v medytsyni. Kerivnytstvo dlya avtoriv, redaktoriv i retsenzentiv. [How to describe statistics in medicine. Guide for authors, editors and reviewers]. Practical Medicine. 2011;47-49. (In Russian).

12. KaroliN.A., RebrovA.P.Arterial hypertension in patientswith bronchialasthma and chronic obstructive pulmonary disease. The Clinician.2011;5(2):20-30. (In Russian). https://Doi.Org/10.17650/1818-8338-2011-2-20-30.

13. Aronson S., Dyke C.M., Stierer K.A. et al. The ECLIPSE trials: comparative studies of clevidipine to nitroglycerin, sodium nitroprusside, and nicardipine for acute hypertension treatment in cardiac surgery patients. Anesth Analg. 2008;107(4):1110-21. doi: 10.1213/ ane.0b013e31818240db.

14. Caram L.M., Ferrari R., Naves C. R. et al. Risk factors for cardiovascular disease in patients with COPD: mild-to-moderate COPD versus severeto-very severe COPD. J. Bras. Pneumol. 2016;42 (3):179-184.

15. Rashid ur $\mathrm{H}$. Electrolyte disturbances in acute exacerbation of COPD. J Enam Med Col. 2019;9(1): 25-9.

16. Gashynova E.Yu. Sistemnyye effekty i komorbidnost' u ambulatornykh patsiyentov s KHOZL [Systemic effects and comorbidity in outpatients with COPD]. Ukrainian pulmonological journal. 2013; 2: 41-45. (In Russian).

17. BarnettK., MercerS.W., Norbury M. et al. Epidemiology of multimorbidity and implications for health care, research, and medical education: a cross-sectional study. Lancet. 2012; 380: 37-43.
18. Morgan A.D., Zakeri R., Quint J.K. Defining the relationship between COPD and CVD: what are the implications for clinical practice? Ther Adv Respir Dis. 2018;12. doi: 10.1177/1753465817750524.

\section{ORCID and contributionship:}

Viktoriia V. Rodionova: 0000-0002-0221-5625 A,B,C

Olha O. Boiko: 0000-0003-0506-0486 D,E,F

\section{Conflict of interest:}

The Authors declare no conflict of interest.

\author{
CORRESPONDING AUTHOR \\ Rodionova V. Viktoriya \\ Dnipropetrovsk Medical Academy \\ of the Ministry of Health of Ukraine \\ 9 V. Vernadskogo st., 49044 Dnipro, Ukraine \\ tel: +38 (067) 9128294 \\ e-mail:dsma@dsma.dp.ua
}

Received: 13.11 .2020

Accepted: 02.03 .2021

A - Work concept and design, B - Data collection and analysis, C - Responsibility for statistical analysis, D-Writing the article, $\mathbf{E}$-Critical review, $\mathbf{F}$ - Final approval of the article 